\title{
relA and Related Loci are Growth Rate Determinants for Escherichia coli in a Recycling Fermenter
}

\author{
By MICHAEL ARBIGE AND WILLIAM CHESBRO* \\ Department of Microbiology, University of New Hampshire, Durham, New Hampshire \\ 03824, U.S.A.
}

(Received 22 May 1981; revised 25 July 1981)

\begin{abstract}
Three sharply distinct phases were found in the growth of Escherichia coli in a continuous fermenter with $100 \%$ cell recycle. They were: an initial phase of batch-type growth reaching exponential rates that terminated abruptly when the glucose concentration in the fermenter fell below the cell's transport threshold; a second phase of linear growth whose rate was dependent on the rate of glucose provision to the fermenter, but whose length was fixed and independent of growth rate; and a third phase of slower linear growth, whose rate was also dependent on the glucose provision rate, characterized by a restriction in RNA accumulation, and indefinite in length. Guanosine $5^{\prime}$-diphosphate $3^{\prime}$-diphosphate (ppGpp) accumulation commenced at the start of phase 2 and rose throughout the phase. It reached a maximum at the start of phase 3, concurrent with the curbing of RNA accumulation; thereafter, the ppGpp concentration was constant unless the rate of glucose supply was increased, at which point it fell to a phase 2 level and the cells returned to a corresponding phase 2 growth rate. The length of growth phase 2 was changed in a precise manner by mutations in the relA, relX and spoT loci. Phase 2 was longer for relA and relX mutants (decreased capability for ppGpp synthesis) and shorter for spoT mutants (decreased capability for ppGpp degradation). It is concluded that the continuously falling energy supply per cell in a recycling fermenter invokes ppGpp accumulation by at least three biochemical mechanisms and that the third, final growth phase in the fermenter is an indefinitely extended manifestation of strong regulation by ppGpp.
\end{abstract}

\section{INTRODUCTION}

In a fermenter with $100 \%$ cell recycle the growing microbial population is completely retained in the fermentation vessel while fresh medium and spent broth are added to and removed from the vessel at equal rates. If the rate at which the carbon-energy substrate is supplied to the growing culture is kept constant, since the total cell mass in the fermenter is continuously increasing, then the rate at which energy is supplied per unit cell mass is continuously dwindling. For such circumstances, calculation of the effect of the maintenance energy requirement upon growth rate (Pirt, 1975; Schultz \& Gerhardt, 1969) predicts a steady decrease toward zero for the growth rate, yielding a growth curve smoothly approaching an asymptote, whose value in turn should be predictable for any particular culture (Chesbro et al., 1979) from its maintenance coefficient. When Escherichia coli was grown in a recycling fermenter under carbon-energy limitation the observed pattern of growth differed significantly from the pattern predicted by application of the maintenance energy concept (Chesbro et al., 1979). Instead, a growth pattern with three phases that were sharply distinct both kinetically and biochemically was observed. The first phase was one of batch-type growth becoming exponential in rate. The exponential growth terminated abruptly when the glucose concentration in the fermentation vessel fell below the concentration limit 
for transport by $E$. coli. In the immediately successive second growth phase, the growth rate was constant and a function of the rate at which glucose was supplied to the culture. The second phase terminated equally abruptly after an interval independent of the growth rate in either phases 1 or 2 . For the strain of $E$. coli B used, this interval was 22-24 h. In the third phase of growth, the growth rate was still constant and a function of the glucose provision rate, but was a fraction of the phase 2 rate. Because the cell mass, $X$, increased continuously during phases 2 and 3 while the growth rate, $\mathrm{d} X / \mathrm{d} t$, was constant and positive within the two phases, the specific growth rate $(\mu),(1 / X) \cdot \mathrm{d} X / \mathrm{d} t$, decreased continuously within both phases, undergoing a change in its own rate of decline within phases 2 and 3. Further, because of the constancy of the growth rate within phases 2 and 3, the mass doubling time became the reciprocal of $\mu$, or $X \cdot \mathrm{d} X / \mathrm{d} t$, so that the length of the doubling time continuously increased in phases 2 and 3 , leading eventually in phase 3 to doubling times in excess of $100 \mathrm{~h}$.

Thus, the recycling fermenter provides access to very slow specific growth rates and very long mass doubling times in a range that has not often been studied in bacteria. This range is reached in the recycling fermenter along highly reproducible growth rate transients which are of fixed length in the case of phase 2, and of indeterminate length in the case of phase 3.

The rates of RNA, DNA, protein and lipopolysaccharide synthesis remained in constant proportion during phase 2 growth, which thus resembled states of balanced growth in this respect. In phase 3, however, the rate of RNA synthesis was depressed more than the other rates of macromolecular syntheses, so that the pattern of macromolecular syntheses in phase 3 resembled that found in cultures with an elevated concentration of the regulatory nucleotide guanosine 5'-diphosphate 3 '-diphosphate (ppGpp), the 'engine of stringency' (Fiil et al., 1977).

We report here results of examining the concentrations of ppGpp in the three phases of an $E$. coli culture grown in the recycling fermenter, and the effects of mutations in the relA, relX and spoT loci upon the growth phase pattern.

\section{METHODS}

Bacteria and growth conditions. Escherichia coli B was the strain previously described (Chesbro et al., 1979). Escherichia coli strains NF859, NF859X (relA1), NF162 (relA1 spoT1), NF161 (spoT1), and NF1035 (relA2 $\mathrm{relX}$ ) were all gifts from J. Gallant, University of Washington, and Escherichia coli $\mathrm{H} 10407\left(\mathrm{Ent}^{+}\right)$, an enterotoxigenic strain, was a gift from S. Falkow, University of Washington. Cultures were maintained on Davis \& Mingioli (1950) basal medium (DMM) agar slants containing $1.25 \mathrm{mg}$ glucose $\mathrm{ml}^{-1}$ with appropriate amino acids added at $20 \mu \mathrm{g} \mathrm{ml}^{-1}$ for the growth of auxotrophic strains. Fresh cultures were transferred from frozen storage at intervals. The basal medium containing a known glucose concentration, $10 \mu \mathrm{g}$ dithiothreitol ml $\mathrm{m}^{-1}$ (Chesbro et al. 1979) and appropriate amino acid supplementation for auxotrophs was used in all experiments in the recycling fermenter, except those involving ${ }^{32} \mathrm{P}$. The medium was prepared and autoclaved in 181 batches.

Recycling fermenter operation. The fermenter system has been described previously (Chesbro et al., 1979). Briefly, sterile medium, flushed with oxygen-free nitrogen, was added to the reaction vessel at a constant rate. The vessel contents $(450 \mathrm{ml}$ ) were pumped continuously acrose a $0.2 \mu \mathrm{m}$ polycarbonate filter (Nuclepore, Pleasanton, Calif., U.S.A.), spent medium was drawn off, and the microbial population was returned to the vessel. Since inflow and outflow rates were equal, the fluid level in the fermenter was constant. The glucose provision rate (GPR) was the product of the substrate concentration of the medium $\left(S_{\mathrm{R}}\right)$ multiplied by the rate at which medium flowed into the fermenter $\left(F_{\mathrm{R}}\right)$. To start, the fermenter was inoculated with approximately $30 \mathrm{ml}$ of a $12 \mathrm{~h}$ anaerobic culture. The reaction vessel was maintained at $30^{\circ} \mathrm{C}$ and the $\mathrm{pH}$ of the medium was kept at 7.0 by the addition of sterile 2 $\mathrm{M}-\mathrm{NaOH}$.

Growth, DNA, RNA and protein analysis. Analyses of microbial mass, culture turbidity, viable count, DNA, RNA and protein were performed as described previously (Chesbro et al., 1979).

Determination of ppGpp. To 41 of modified DMM lcontaining $\left(\mathrm{g} \mathrm{l}^{-1}\right): \mathrm{K}_{2} \mathrm{HPO}_{4}, 0.087 ;\left(\mathrm{NH}_{4}\right)_{2} \mathrm{SO}_{4}, 1.0$; sodium citrate, 0.5 ; bicine, $16.317 ; \mathrm{MgSO}_{4} .7 \mathrm{H}_{2} \mathrm{O}, 0.1$ (autoclaved separately); glucose, 3.75 (autoclaved separately); dithiothreitol, 0.01 ; at $\mathrm{pH} 7.0$ ] was added $25 \mathrm{mCi}(925 \mathrm{MBq})$ of carrier-free [ ${ }^{32} \mathrm{P}$ ]orthophosphate (New England Nuclear). After inoculation of the fermenter, $2 \mathrm{ml}$ samples were withdrawn at various intervals and made $2 \mathrm{M}$ in formic acid by adding $153 \mu \mathrm{l}$ of concentrated formic acid. They were then frozen at $-70^{\circ} \mathrm{C}$, thawed, centrifuged, and the supernates were dried and resuspended in $200 \mu \mathrm{l}$ of $10 \%(\mathrm{v} / \mathrm{v})$ isopropanol, thus concentrating the suspension $10 \times$. 
The ppGpp in these formic acid extracts was separated by polyethyleneimine (PEI)-cellulose thin-layer chromatography (J. T. Baker Chemical Co., Phillipsburg, N.J., U.S.A.). The sheets were prewashed once in deionized water and dried. One-dimensional separation of the nucleotides was achieved by spotting between 2.5 and $10 \mu \mathrm{l}$ of ${ }^{32} \mathrm{P}$-labelled nucleotide extract and chromatographing in $1.5 \mathrm{M}$-potassium phosphate buffer, $\mathrm{pH} 3.4$ (Cashel et al., 1968). ${ }^{32} \mathrm{P}$-labelled nucleotides were detected by autoradiography using Kodak XR-5 X-ray film exposed for 24-72 h. Spots whose mobility corresponded to authentic standards of ppGpp and GTP (PL Biochemicals, Milwaukee, Wis., U.S.A.) were cut out and counted in a scintillation counter.

For qualitative identification of ppGpp and other nucleotides, a two-dimensional system was employed (Cashel et al., 1968). The formic acid extracts were chromatographed in the first dimension with $3 \cdot 3 \mathrm{M}$-ammonium formate $/ 4.2 \%(\mathrm{w} / \mathrm{v})$ boric acid, $\mathrm{pH}$ adjusted to 7.0 with $\mathrm{NH}_{4} \mathrm{OH}$. Sheets were then soaked in methanol for $5 \mathrm{~min}$, water for $15 \mathrm{~min}$, and dried. The solvent for the second dimension was $0.85 \mathrm{M}-\mathrm{KH}_{2} \mathrm{PO}_{4}, \mathrm{pH} \mathrm{3.4}$.

Cultures were tested for the relative production of ppGpp and guanosine 5'-triphosphate 3'-diphosphate (pppGpp) by the procedure described by Engel et al. (1979). Cells grown overnight on broth agar plates were transferred with a toothpick to make turbid $200 \mu \mathrm{l}$ of a Tris minimal glucose medium (Kaempfer \& Magasanik, 1967) containing $40 \mu \mathrm{M}$-phosphate, $1 \mathrm{mg}$ serine hydroxamate $\mathrm{ml}^{-1}$ (Sigma), $300 \mu \mathrm{g} \mathrm{L}$-valine $\mathrm{ml}^{-1}$ (Sigma) and $10 \mu \mathrm{Ci}(370 \mathrm{kBq}){ }^{32} \mathrm{P} \mathrm{ml} \mathrm{m}^{-1}$. This suspension was incubated for $1 \mathrm{~h}$ at $37^{\circ} \mathrm{C}$, then $50 \mu \mathrm{l}$ of $13 \mathrm{M}$-formic acid was added, and the solution was frozen for $15 \mathrm{~min}$. Samples $(10 \mu \mathrm{l})$ were spotted on PEI-cellulose chromatography plates, developed for $10 \mathrm{~cm}$ with $1.5 \mathrm{M}-\mathrm{KH}_{2} \mathrm{PO}_{4}, \mathrm{pH} 3.4$ and exposed to X-ray film overnight.

\section{RES ULT S}

\section{Behaviour of $E$. coli $B$ and $H 10407$ in the recycling fermenter}

Growth of $E$. coli B in the recycling fermenter at a GPR of $387 \mu \mathrm{mol} \mathrm{h}^{-1}$ is shown in Fig. 1. Phase 1 growth consisted of a lag period followed by exponential growth. When the glucose concentration in the fermenter fell below $0.1 \mu \mathrm{g} \mathrm{m}^{-1}$, the transport limit of $E$. coli (Chesbro et al., 1979; Shehata \& Marr, 1971), phase 1 ended and phase 2 began. In this second phase the growth rate was constant. For $E$. coli B, phase 2 lasted $22-24 \mathrm{~h}$ before phase 3 commenced (Chesbro et al., 1979). The growth rate in phase 3 dropped to a new, lower value which then remained constant for at least another $150 \mathrm{~h}$. Because the growth rate was constant in phases 2 and 3, while cell mass continuously increased, the specific growth rate $(\mu)$ fell throughout phase 2 and phase 3 , and since mass doubling time in these phases of linear growth was $1 / \mu$, the doubling time increased continuously.

Figure 1 shows changes in colony-forming units, biomass, DNA, RNA and protein in $E$. coli $\mathrm{B}$ before and after phase 3 cells were subjected to an upshift in GPR. The upshift was imposed by increasing fourfold the flow rate of medium into the fermenter. During phase 2, the concentrations of DNA, RNA and protein increased in constant proportion. At the onset of phase 3, the rates of synthesis of these parameters decreased, but not in proportion (Table 1 ), and the cells became impoverished in RNA as its synthesis dropped by $80 \%$ from its phase 2 rate. In comparison, protein synthesis dropped by $43 \%$ from its phase 2 rate.

For the first $6 \mathrm{~h}$ after the fourfold upshift, the rate of cell division was 13 -fold, and the rate of biomass increase was 7 -fold, greater than their respective rates immediately before the upshift. However, the rate of biomass increase was very nearly four times its phase 2 value. Protein synthesis increased 5-fold and the rate of RNA synthesis about 40 -fold. The increase in the rate of DNA synthesis was relatively modest, about 2 -fold. After $10 \mathrm{~h}$, its rate of synthesis doubled fairly abruptly. At the same time, the rates of RNA synthesis, cell division and growth commenced falling, apparently toward asymptotes.

Figure 2 shows the growth pattern of strain $\mathrm{H} 10407$ in the recycling fermenter at a GPR of $412 \mu \mathrm{mol} \mathrm{h}{ }^{-1}$. The most obvious difference from the pattern observed with strain $B$ is in the length of phase 2 - in this case close to $50 \mathrm{~h}$. When $\mathrm{H} 10407$ was grown at various GPR, the growth rates in phases 2 and 3 were dependent on GPR, but the length of phase 2 remained at $50 \mathrm{~h}$, as it had remained at 22-24 h for $E$. coli B despite changes in GPR and growth rate (Chesbro et al., 1979). 

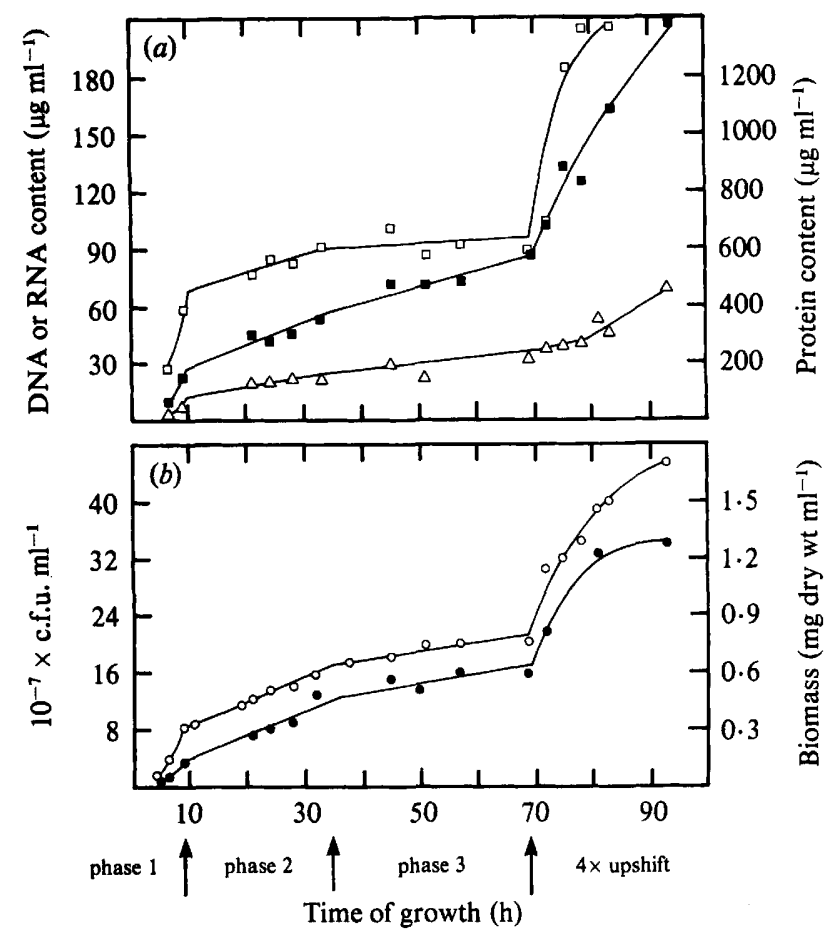

Fig. 1. Growth of $E$. coli $\mathrm{B}$ in a recycling fermenter at $\mathrm{pH} 7.0,30^{\circ} \mathrm{C}$, and a GPR of $387 \mu \mathrm{mol}$ glucose

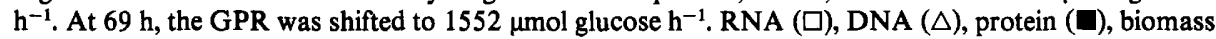
$(\mathrm{O})$, colony-forming units (c.f.u.) (O).

Table 1. Change in culture parameters when a phase 3 culture of $E$. coli $B$ was exposed to a fourfold increase in glucose provision rate

The GPR was $387 \mu \mathrm{mol} \mathrm{h}^{-1}$ at an $F_{\mathrm{R}}$ of $55.8 \mathrm{ml} \mathrm{h}^{-1}$ during phase 2 and the first $45 \mathrm{~h}$ of phase $3 ; F_{\mathrm{R}}$ was then increased to $216 \mathrm{ml} \mathrm{h}^{-1}$. The phases are defined in the text.

\begin{tabular}{|c|c|c|c|c|}
\hline \multirow[b]{2}{*}{ Parameter } & \multirow{2}{*}{$\begin{array}{l}\text { Percentage } \\
\text { increase } 6 \mathrm{~h} \\
\text { after upshift }\end{array}$} & \multicolumn{3}{|c|}{ Rate of change $\left(\mu \mathrm{g} \mathrm{ml}^{-1} \mathrm{~h}^{-1}\right)$} \\
\hline & & Phase 2 & Phase 3 & $\begin{array}{c}\text { After } \\
\text { upshift* }\end{array}$ \\
\hline Dry weight & 43 & $14 \cdot 5$ & 3.8 & $59 \cdot 0$ \\
\hline Protein & 38 & $13 \cdot 5$ & 7.8 & $39 \cdot 0$ \\
\hline RNA & 87 & $1 \cdot 6$ & 0.3 & $13 \cdot 0$ \\
\hline DNA & 5 & $1 \cdot 2$ & 0.3 & 0.7 \\
\hline Bacterial numbers & 30 & - & - & - \\
\hline
\end{tabular}

\section{Accumulation of ppGpp}

The changes in RNA and protein synthetic rates at the entry of the culture into phase 3, their relative proportions during phase 3 , and their changes after the upshift resembled similar changes in many strains of $E$. coli during carbon-energy shifts (Gallant, 1979; Nierlich, 1978). Such changes have been shown to be closely associated with cellular concentrations of ppGpp (Gallant, 1979; Nierlich, 1978).

Figure 3 shows the concentration of ppGpp in $E$. coli $\mathrm{B}$ at different times during the three phases and after a fourfold upshift in GPR. The concentration of ppGpp in phase 2 was 


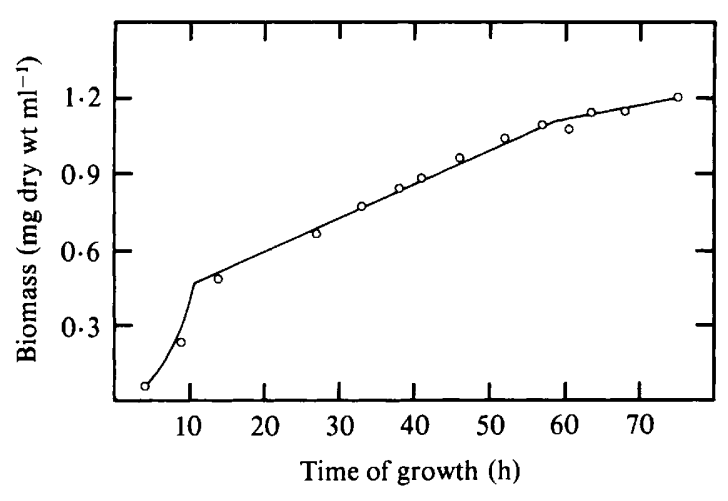

Fig. 2

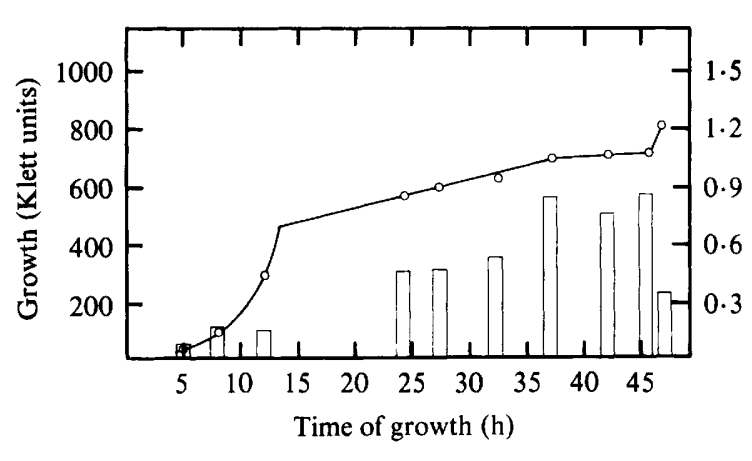

Fig. 3

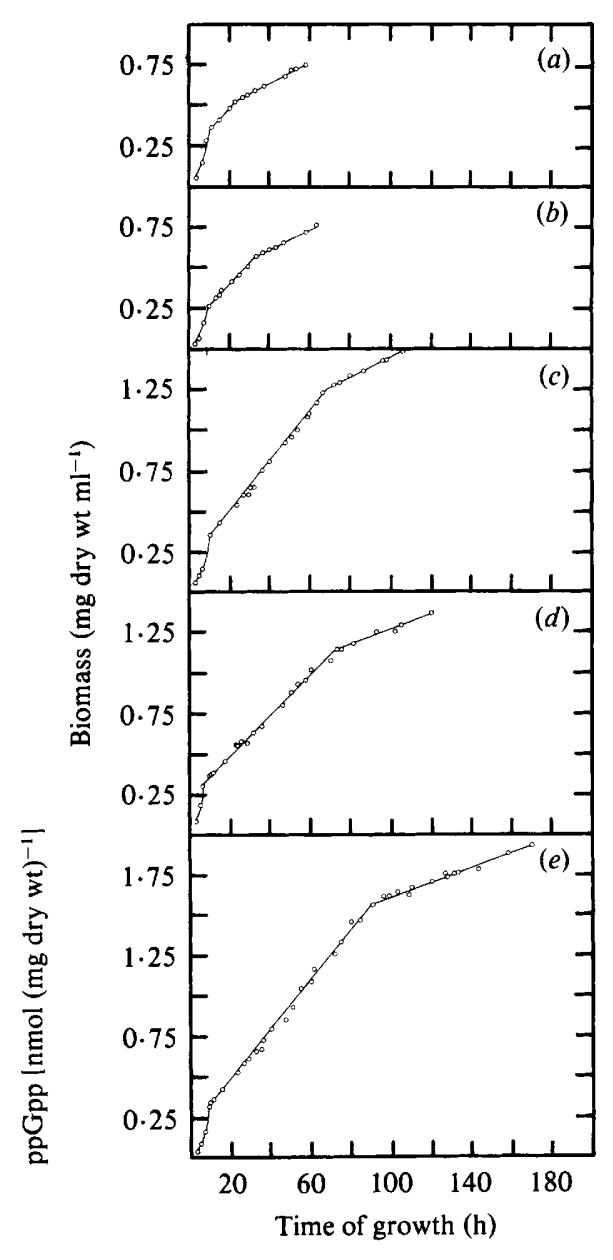

Fig. 4

Fig. 2. Growth of $E$. coli $\mathrm{H} 10407$ in a recycling fermenter at pH $7 \cdot 0,30^{\circ} \mathrm{C}$, and a GPR of $412 \mu \mathrm{mol}$ glucose $h^{-1}$.

Fig. 3. ppGpp content of $E$. coli B growing in a recycling fermenter at a GPR of $1250 \mu$ mol glucose $\mathrm{h}^{-1}$ until shifted to $4800 \mu \mathrm{mol}$ glucose $\mathrm{h}^{-1}$ at $45 \mathrm{~h}$. Other conditions were as in Fig. 1. Klett units $(O)$, ppGpp (bars).

Fig. 4. Growth of a wild-type and $r e l$ system mutants of $E$. coli in a recycling fermenter at pH 7.0, $30^{\circ} \mathrm{C}$. The cultures and respective GPR ( $\mu$ mol glucose $\mathrm{h}^{-1}$ ) were: (a) NF161 (spoT), 416; (b) NF 162 (relA1 spoT), 408; (c) NF859 (wild-type), 433; (d) NF859X (relA1), 416; (e) NF1035 (relA2 relX), 421.

double that in phase 1 and seemed to increase slightly throughout the phase. Its concentration nearly doubled again in phase 3 cells, then returned close to its early phase 2 concentration immediately after the glucose upshift.

\section{Growth pattern of relA, relX and spoT strains of $E$. coli in the recycling fermenter}

Two routes for the synthesis of ppGpp are believed to exist. The first involves the relA gene product, a ribosome-bound ATP:GTP pyrophosphate transferase whose activity in the synthesis of pppGpp and ppGpp requires the presence of mRNA and uncharged, codon-specific tRNA. These requirements couple this route to the cell's amino acid supply. 


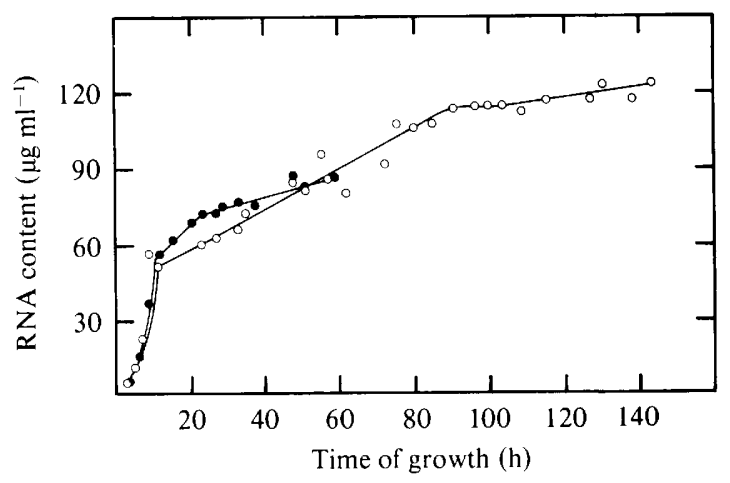

Fig. 5. Accumulation of RNA by $E$. coli strains NF161 (O) and NF1035 (O) in the experiments shown in Fig. 4.

(Because carbon source depletion also depletes the cell's amino acid supply, the $\mathrm{relA}$ gene product is also coupled indirectly to the carbon source supply.) The second system involves the relX gene product, and possibly the relS locus (Engel et al., 1979) whose mode of action is less well defined, but which seems to couple ppGpp synthesis to energy downshifts. In this route, $\mathrm{pppGpp}$ is not an intermediate.

Regardless of the route by which ppGpp is made, it is subject to degradation by the spoT gene product, guanosine $3^{\prime}, 5^{\prime}$-bis(diphosphate) $3^{\prime}$-pyrophosphohydrolase (ppGppase), an enzyme that also is ribosome-associated (Fiil et al., 1977; Richter et al., 1979), but which is inhibited by uncharged tRNA (Richter, 1980a) and possibly requires the existence of a transmembrane proton gradient (DeBoer et al., 1975; Tetu et al., 1980) for its activity. Glucose exhaustion (which presumably collapses the proton gradient) causes a rapid decrease in ppGpp degradation (DeBoer et al., 1975; Tetu et al., 1980), and it has been argued that inhibition of ppGppase plays an important role in elevating ppGpp concentrations during conditions of energy limitation as well as in amino acid starvation.

Mutations in the relA and relX loci produce a decreased ability to accumulate ppGpp and therefore should cause a delay in the appearance of phase 3 , and a longer phase 2 , if ppGpp is the determinant of the phase 2 to phase 3 transition. Conversely, in spoT strains, the diminished ppGpp degrading capability should bring about a faster accumulation of ppGpp, thus accelerating the appearance of phase 3 and shortening phase 2 . Figure 4 shows that these loci affected the growth-phase pattern in the recycling fermenter by lengthening or shortening phase 2 in a manner consistent with their known effects upon ppGpp synthesis and the supposition that it is the accumulation of ppGpp that brings about phase 3 growth.

Strain NF1035 (relA2 $\mathrm{rel} X$ ), although retaining some capability for ppGpp synthesis (Pao \& Gallant, 1978), has the most severely restricted capability for such synthesis among the strains studied, which, coupled with its possession of an active ppGppase, led to the expectation that it would either have the longest phase 2 of any strain studied, or would not enter phase 3 at all. In fact, it did enter phase 3 growth after the longest phase 2 yet observed, suggesting that ppGppase activity was ultimately depressed enough by either energy deficiency, or accumulation of uncharged tRNA, or both, to permit accumulation of ppGpp to the concentration necessary for phase 3 growth behaviour to begin.

Figure 5 shows the changes in RNA synthesis during the growth of strains NF161 and NF1035, which had the shortest and longest phase 2 growth intervals, respectively. The abrupt decrease observed in RNA synthesis at the phase 2/phase 3 transition was consistent with the expected effect of an increase in ppGpp concentration at that time. The other strains showed similar changes in RNA synthesis.

The effect of the individual loci upon the length of phase 2 is shown in Table 2 . A change in the spoT1 locus had about three times greater effect on the length of phase 2 than a change in 
Table 2. Apparent growth yields and lengths of the phase 2 growth interval for $E$. coli strains of known rel system genotype shown in Fig. 4

\begin{tabular}{ccc}
$\begin{array}{c}E . \text { coli } \\
\text { strain }\end{array}$ & $\overbrace{\text { Phase 2 }}^{\text {Apparent growth yield }\left(Y_{\mathrm{a}}\right)}$ & $\begin{array}{c}\text { Phase } 3 \\
\left.\text { [mg biomass }(\mu \mathrm{mol} \text { glucose })^{-1}\right]\end{array}$ \\
$\begin{array}{c}\text { NF161 } \\
(\text { spoT })\end{array}$ & 0.017 & 0.007 \\
$\begin{array}{c}\text { NF162 } \\
(\text { relA1 spoT) }\end{array}$ & 0.014 & 0.007 \\
$\begin{array}{c}\text { NF859 } \\
(\text { wild-type) }\end{array}$ & 0.016 & 0.006 \\
$\begin{array}{c}\text { NF859X } \\
(\text { relAl) }\end{array}$ & 0.014 & 0.005 \\
$\begin{array}{c}\text { NF1035 } \\
(\text { relA2 relX) }\end{array}$ & 0.016 & 0.005 \\
\hline
\end{tabular}

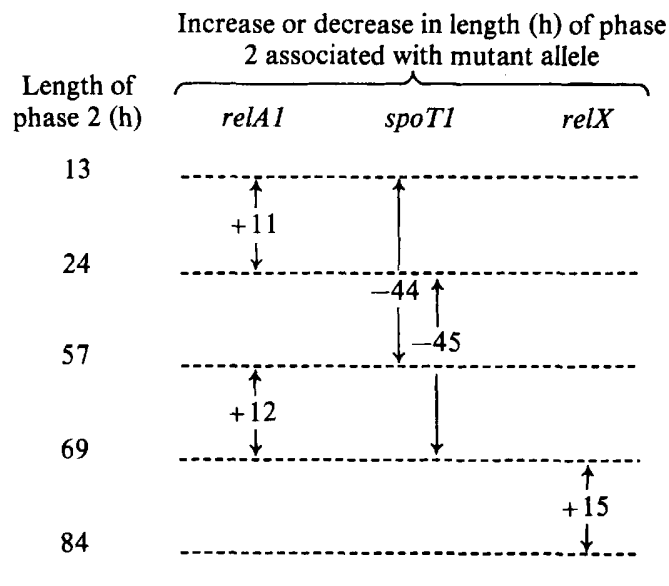

the relX locus, and about four times greater than a change in the relA locus. However, changes in the loci had no obvious effect on the apparent growth yield $\left(Y_{\mathrm{a}}\right)$ in phase 2 growth, which averaged $0.016 \mathrm{mg}$ cell dry wt ( $\mu \mathrm{mol}$ glucose) $)^{-1}$. There did seem to be a trend in $Y_{\mathrm{a}}$ values for phase 3 growth that was inversely correlated with the length of phase 2: $Y_{\mathrm{a}}$ for phase 3 decreased from $0.007 \mathrm{mg}$ cell dry wt ( $\mu \mathrm{mol}$ glucose) $)^{-1}$ for strain NF161 to $0.005 \mathrm{mg}$ cell dry wt ( $\mu \mathrm{mol}$ glucose) $)^{-1}$ for strain NF1035. The meaning of this correlation, assuming it is significant, is not yet clear to us.

\section{Comparative synthesis of pppGpp and ppGpp in different $E$. coli strains}

Although autoradiograms of $E$. coli B extracts showed the presence of ppGpp in this strain, pppGpp was absent. The latter nucleotide is believed to be the precursor of $\mathrm{ppGpp}$ in vivo when ppGpp is synthesized by the $\mathrm{rel} \mathrm{A}^{+}$gene product (stringent factor) during amino acid starvation. Tight mutants of the relA locus, such as relA1, show no increase in the concentration of either nucleotide above basal levels when subjected to amino acid starvation (Gallant, 1979). However, both parent and relA mutant strains show elevated ppGpp, but not pppGpp, concentrations when subjected to a carbon-energy downshift (Gallant, 1979). This synthesis seems to involve the relX and relS loci (Engel et al., 1979) but can be independent of both the relA and relX loci (Atherly, 1979). The spo $T^{+}$gene product, ppGpp pyrophosphatase, affects the relative accumulations of the two nucleotides in a complex way dependent on the genetic background of a particular strain (Fiil et al., 1977).

A carbon-energy downshift of the sort imposed by the recycling fermenter necessarily subjects the cells to both an energy shortage and amino acid starvation as the supply of glucose-derived intermediates per cell dwindles. The resemblance of the growth pattern of $E$. coli $\mathrm{B}$ in the fermenter to that of strain NF162 (relA1 spoT1), and of strain H10407 to strain NF859 $\left(\mathrm{relA}^{+} \mathrm{relX}^{+}\right.$spoT $\left.T^{+}\right)$, led to the expectation that each pair of strains should show corresponding behaviour in the accumulation of pppGpp and ppGpp when tested by the procedure of Engel et al. (1979), which subjects cells in batch growth to a simultaneous energy downshift and amino acid starvation. When tested in this way, E. coli H10407 and NF859 produced both nucleotides, whereas $E$. coli B produced only ppGpp, as did NF162 and NF859X (relA1). Strain NF161 (relA ${ }^{+}$spoT), which is isogenic with NF162, produced a small but detectable amount of pppGpp in addition to ppGpp. 
The close resemblance between the growth of strains B and NF162 in the recycling fermenter and in their production of nucleotides suggested that strain B, like NF162, might also show a reduced capacity for ppGpp degradation. The stability of ppGpp in $E$. coli B cells was tested by treating phase 3 cells with arsenate. Following exposure to arsenate, the half-life of ppGpp was greater than 16 min, while that of GTP, for comparison, was of the order of 3 min. Since ppGpp has a half-life of less than $1 \mathrm{~min}$ in spo $T^{+}$cells (Fiil et al., 1977), E. coli B is either deficient in ppGpp pyrophosphatase activity, in addition to being deficient in stringent factor activity, or arsenate inhibited the pyrophosphatase in some way, perhaps by lowering the transmembrane proton gradient which has been suggested (Tetu et al., 1980) as important to the in vivo activity of the enzyme.

\section{DISCUSSION}

In phase 3, the ultimate growth stage we have been able to produce in the recycling fermenter, the cellular concentration of ppGpp is comparable with those produced in populations of $E$. coli by carbon-energy source downshifts (Johnsen et al., 1977; Pao \& Gallant, 1978; Winslow, 1971), and protein and RNA syntheses behave in ways typical of ppGpp restriction of rRNA synthesis.

Energy-deficient cells have frequently been produced as a means of studying ppGpp synthesis, its effects, and more generally, the regulation and co-ordination of macromolecular syntheses. Strategies for producing such cells have included their being subjected to a shift from a more preferred substrate, usually glucose, to a less preferred one, such as succinate (Lazzarini et al., 1971); permitting energy substrate exhaustion to occur (Boquet $e$ al., 1973; Jacobson \& Jacobson, 1980); starvation by temperature shifts that inhibit thermally sensitive steps of energy pathways (Cashel, 1975; Lund \& Kjeldgaard, 1972); exposure of anaerobes to oxygen (Glass et al., 1978) or imposition of anaerobiosis on aerobic cultures (Lund \& Kjeldgaard, 1972); use of analogues competitive with energy substrates (Hansen et al., 1975; Johnsen et al., 1977); and employment of drugs that uncouple oxidative phosphorylation or inhibit substrate level phosphorylation (Cashel, 1975; Richter, 1980 b). It has been argued (Jacobson \& Jacobson, 1980) that categorizing all these strategies as 'energy-source shiftdowns' is suspect since the different treatments affect regulatory behaviour in demonstrably different ways and information about their effects on intermediary metabolism and cellular energy balance is usually absent.

At least some of this criticism is avoided in the production of energy-deficient cells in a recycling fermenter, since dissimilatory metabolism as reflected in fermentation balances is constant throughout the three phases, biomass yield per unit glucose utilized is constant within each phase, and the composition of the milieu is constant throughout the phases unless experimentally altered (Chesbro et al., 1979).

An important feature of the recycling fermenter, as a strategy for calling into play processes that regulate and co-ordinate biosynthetic events at the genetic/metabolic level during energy shortage, is the considerable expansion of the periods of time over which these processes are evoked and exert their influence: the rise time between basal and maximum observed concentrations of ppGpp in cells growing exponentially with doubling times of $1-2 \mathrm{~h}$ is less than $1 \mathrm{~h}$, while the comparable time for $E$. coli $\mathrm{B}$ in the recycling fermenter is the length of phase 2 , i.e. $22-24 \mathrm{~h}$.

The length of phase 2 is constant within rather close limits for a given strain of $E$. coli and independent of growth rate (Chesbro et al., 1979), that is, its length seems to be determined by a cellular 'clockwork'. Since the termination of phase 2 is concurrent with the accumulation of ppGpp to a concentration sufficient to curb RNA accumulation, the 'clockwork' that determines the length of phase 2 is the linkage of ppGpp synthesis and degradation to the rate of energy supply per cell. 
Because the rates of macromolecular synthesis in phase 3 resemble in their relative proportions those characteristic of cultures in the stringent response state, it was not surprising to find ppGpp elevated in these cells. Since phase 2 cells resemble cells in steady state growth in the constant proportions of their macromolecular syntheses, however, and therefore are not overtly undergoing the stringent response, it was surprising to find the concentration of ppGpp rising as soon as the glucose concentration in the culture broth fell below the limits of the phosphotransferase system (the condition initiating phase 2) and remaining at a concentration between the basal level of phase 1 and the ultimate level of phase 3. Lagosky \& Chang (1980) have recently re-evaluated the relation between basal pool concentrations of ppGpp and RNA synthesis in $E$. coli (Hansen et al., 1975) using an analytical procedure that finds the cellular concentration of ppGpp to be three to five times that shown by acid extraction procedures. They found that RNA synthesis responded relatively sensitively to changes in the concentration of $\mathrm{ppGpp}$ in relA1 spoT1 cultures undergoing amino acid starvation and resupplementation. It is not clear how this relates to the apparent absence of such an effect on RNA synthesis in our phase 2 cultures. The experimental conditions varied considerably between their study and ours: the culture in the recycling fermenter is undergoing no abrupt, exogenously imposed transition in growth rate due to either amino acid or energy deficiency during phase 2, and the observation interval, 22-24 $\mathrm{h}$, is considerably longer than the $3 \mathrm{~h}$ maximum interval used by Lagosky \& Chang (1980), or, indeed, the observation interval of any studies on cell responses to changing ppGpp concentrations of which we are aware.

However, phase 2 cells may be showing a response to the increased ppGpp concentration in a different area of synthesis since in $E$. coli $\mathbf{B}$ the division rate is slowing and cells are becoming progressively larger through an increase in cell diameter (Chesbro et al., 1979). Thus, while the concentration of ppGpp in phase 2 cells may not be high enough to affect the activity of RNA polymerase and the transcription of rRNA, it may be high enough to affect the activity of the enzymes of phospholipid and peptidoglycan synthesis which are susceptible to ppGpp regulation (Gallant, 1979; Nierlich, 1978), and thus the synthesis of membrane and septum and the elongation of the cell. It therefore seems likely that the different concentrations of ppGpp in phase 2 and phase 3 cells are responsible for the temporal separation between the alteration in rates of processes determining cell geometry and volume that takes place in phase 2 and the alteration in rates of processes determining cell mass that takes place in phase 3 .

Different questions arise in connection with the observed changes in the rates of macromolecular syntheses and cell division that accompanied a fourfold upshift in glucose provision rate in phase 3 . The global growth rate became four times the phase 2 rate rather than the phase 3 rate, while the ppGpp concentration dropped to about that of phase 2 . The rates of RNA and protein synthesis and of cell division rose immediately after the upshift while the major increase in the rate of DNA synthesis lagged behind the other rates by about $10 \mathrm{~h}$. This is the reverse of the situation usually observed in cells growing exponentially (Brunschede et al., 1977) when they are subjected to an energy or temperature upshift. In that case, the change in cell division rate lags behind the change in DNA synthesis rate. This has been interpreted to mean that rounds of DNA synthesis underway when the shift was made had to be completed before the rate of cell division could increase (Loeb et al., 1978), and that the rate of cell elongation was fixed for the duration of any division cycle.

In our experiments, the elevated DNA content per colony-forming unit in phase 3 just prior to upshift was very close to that reported by Tang \& Helmstetter (1980) for a temperature-sensitive, DNA-initiation mutant of $E$. coli $\mathrm{B} / \mathrm{r}$ shifted to a non-permissive temperature. They accounted for DNA enrichment in their culture as being due to the presence of multiple chromosome forks. Whether the DNA enrichment in phase $3 E$. coli B cells was due to multiple forks on finished chromosomes, or to multiple copies of finished chromosomes, either explanation would fit the possibility that, during phase 3 , the interdiction 
of elongation and septum formation by ppGpp caused the accumulation of 'primed sites' (Sloan \& Urban, 1976) in zones of cell wall addition and incipient septation. These 'primed sites' would result in cells poised for completion of cell elongation, septum formation and cell division whose potential for these actions was realized immediately after the upshift reduced the ppGpp concentration and provided carbon-energy at a higher rate.

This work was supported in part by grant DAAG29-79-C-0186 from the U.S. Army Research Office, including support for M. Arbige. In addition, the technical assistance of Robin Eifert, Melissa Rochkind and Leslie Linkkila is acknowledged.

\section{REFERENCES}

ATHERLy, A. G. (1979). Deletion of relA and relX in Escherichia coli has no effect on basal or carbondownshift ppGpp synthesis. In Regulation of Macromolecular Synthesis by Low Molecular Weight Mediators, pp. 53-66. Edited by G. Koch \& D. Richter. New York: Academic Press.

Boquet, P. L., Deuynck, M. A., Monnier, C., Fromageot, P. \& RoeschenthaleR, R. (1973). Inhibition of stable RNA synthesis by levallorphan in Escherichia coli. European Journal of Biochemistry 40, 31-42

BrunsChede, H., Dove, T. L. \& BREMER, H. (1977). Establishment of exponential growth after a nutritional shiftup in Escherichia coli $\mathrm{B} / \mathrm{r}$ : accumulation of deoxyribonucleic acid, ribonucleic acid and protein. Journal of Bacteriology 129, 1020-1033.

Cashel, M. (1975). Regulation of bacterial ppGpp and pppGpp. Annual Review of Microbiology 29, 301-318.

Cashel, M., Lazzarini, R. \& Kalbacher, M. (1968). An improved method for thin layer chromatography of nucleotide mixtures containing ${ }^{32}$ P-labeled orthophosphate. Journal of Chromatography 40, 103-109.

Chesbro, W., Evans, T. \& Eifert, R. (1979). Very slow growth of Escherichia coli. Journal of Bacteriology 139, 625-638.

Davis, B. D. \& Mingioli, E. (1950). Mutants of Escherichia coli requiring methionine or vitamin $\mathrm{B}_{12}$. Journal of Bacteriology 60, 17-18.

DeBoer, H., Bakker, A., Weyer, W. \& Gruber, M. (1975). The role of energy generating processes in the degradation of guanosine tetraphosphate, ppGpp, in Escherichia coli. Biochimica et biophysica acta 432, 361-368.

Engel, J. A., Sylvester, J. \& Cashel, M. (1979). Guanosine $3^{\prime} 5^{\prime}$-bispyrophosphate is a dispensable metabolite. In Regulation of Macromolecular Synthesis by Low Molecular Weight Mediators, pp. 25-38. Edited by G. Koch \& D. Richter. New York: Academic Press.

Fill, N., Willumsen, B., Freisen, J. \& von Meyenburg, K. (1977). Interaction of alleles of the rel $A$, rel $C$, and spoT genes in Escherichia coli: analyses of the interconversion of GTP, ppGpp, and pppGpp. Molecular and General Genetics 150, 87-101.

Gallant, J. A. (1979). Stringent control in Escherichia coli. Annual Review of Genetics 13, 393-415.

Glass, T. L., Holmes, M. W., Hylemon, P. B. \& StellwaG, E. J. (1978). Synthesis of guanosine tetra and penta phosphates by the obligately anaerobic bacterium, Bacteroides thetaiotaomicron in response to molecular oxygen. Journal of Bacteriology 137, 956-962.

Hansen, M. T., PATo, M. L., Molin, S., Fill, N. P. \& von MeyenBuRG, K. (1975). Simple downshift and resulting lack of correlation between ppGpp pool size and ribonucleic acid accumulation. Journal of Bacteriology 122, 585-591.

JACOBSON, L. A. \& JACOBSON, L. J. (1980). Control of protein synthesis in Escherichia coli. Strain differences in control of translational initiation after energy source shiftdown. Journal of Bacteriology $142,888-898$.

Johnsen, K., Molin, S., Karlstrom, O. \& MaAle, O. (1977). Control of protein synthesis in Escherichia coli. Analysis of an energy source shiftdown. Journal of Bacteriology 131, 18-29.

KAEMPFER, R. O. R. \& MAGASANIK, B. (1967). Effect of infection with $\mathrm{T}$-even phage on the inducible synthesis of $\beta$-galactosidase in E. coli. Journal of Molecular Biology 27, 453-468.

LAGosky, P. \& ChaNG, F. N. (1980). Influence of amino acid starvation on guanosine 5 -diphosphate 3'-diphosphate basal level synthesis in Escherichia coli. Journal of Bacteriology 144, 499-508.

Lazzarini, R. A., Cashel, M. \& Gallant, J. (1971). On the regulation of guanosine tetra phosphate levels in stringent and relaxed strains of Escherichia coli. Journal of Biological Chemistry 246, 43814385.

Loeb, A., McGrath, B. E., Navre, J. M. \& Pierucci, O. (1978). Cell division during nutritional upshifts of Escherichia coli. Journal of Bacteriology 136, 631-637.

LuND, E. \& KJeldgAARD, N. O. (1972). Metabolism of guanosine tetraphosphate in Escherichia coli. European Journal of Biochemistry 28, 316-326.

NieRLICH, D. P. (1978). Regulation of bacterial growth, RNA, and protein synthesis. Annual Review of Microbiology 32, 393-432.

PaO, C. C. \& Gallant, J. (1978). A gene involved in the metabolic control of ppGpp synthesis. Molecular and General Genetics 158, 271-277.

PIRT, S. J. (1975). Principles of Microbe and Cell Cultivation, pp. 63-75. Oxford: Blackwell Scientific Publications.

RICHTER, D. (1980a). Uncharged tRNA inhibits guanosine 3'5'-bis(diphosphate) 3'-pyrophosphohydrolase (ppGppase), the spoT gene product from Escherichia coli. Molecular and General Genetics 178, 325-327. 
RichteR, D. (1980b). In vitro degradation of guanosine 3'5'-bis(diphosphate) (ppGpp) by the spoT gene product (ppGppase) from auxotrophic strains of Escherichia coli: effects of various antibiotics and drugs. Archives of Microbiology 124, 229-232.

Richter, D., FeHR, S. \& HARDER, R. (1979). The guanosine $3^{\prime} 5^{\prime}$-bis(diphosphate) (ppGpp) cycle. Comparison of synthesis and degradation of guanosine $3^{\prime} 5^{\prime}$-bis(diphosphate) in various bacterial systems. European Journal of Biochemistry 99, 57-64.

Schultz, J. S. \& Gerhardt, P. (1969). Dialysis culture of microorganisms: design, theory, results. Bacteriological Reviews 33, 1-47.

ShehatA, T. E. \& MARR, A. G. (1971). Effect of nutrient concentration on the growth of Escherichia coli. Journal of Bacteriology 107, 210-215.
Sloan, J. B. \& URBAN, J. E. (1976). Growth response of Escherichia coli to nutritional shiftup: immediate division stimulation in slow growing cells. Journal of Bacteriology 128, 302-308.

TANG, M. S. \& Helmstetter, C. (1980). Coordination between chromosome replication and cell division in Escherichia coli. Journal of Bacteriology 141, 1148-1156.

Tetu, C., Dassa, E. \& Boquet, P. (1980). The energy dependent degradation of guanosine 5 '-diphosphate 3'-diphosphate in Escherichia coli. Lack of correlation with ATP levels in vivo and role of the transmembrane proton gradient. European Journal of Biochemistry 103, 117-124.

WinsLOW, R. M. (1971). A consequence of the rel gene during a glucose to lactose downshift in Escherichia coli. Journal of Biological Chemistry 246, 48724877. 